\title{
Alice in Wonderland: A Mythical Journey
}

\author{
Marilu Monteiro ${ }^{1}$, Francisco Antonio Pereira Fialho ${ }^{2}$
}

\begin{abstract}
${ }^{1}$ Master Student in the Programa de Pós-graduação em Engenharia e Gestão do Conhecimento at Santa Catarina Federal University, Brazil ${ }^{2}$ Dr. Eng.; Titular Professor at Santa Catarina Federal University; Brazil
\end{abstract}

Received: 03 Jul 2021; Received in revised form: 02 Aug 2021; Accepted: 10 Aug 2021

(C2021 The Author(s). Published by TheShillonga. This is an open access article under the CC BY license

(https://creativecommons.org/licenses/by/4.0/)

\begin{abstract}
The theme of this work is a study of theories about the myth of the hero lived out by the character Alice, of the film Alice in Wonderland, directed by Tim Burton and based on the work of the writer Charles Lutwidge Dodgson, under the pseudonym Lewis Carroll in 1865. A brief psychological analysis is made of the relationship of the fantastic narrative with the process of individuation of the protagonist and the symbolic representations in the psychic development that occurs, through her mythical experience of the "hero's journey" that was elaborated by Joseph Cambpell in The Hero of a Thousand Faces. This theory presents the various stages of the mythical journey of the hero, trajectory which is marked by complications, trials and lessons that the hero must undertake to develop inwardly. At the end of the journey Alice not only develops herself but also interferes with the local order of her community which is governed by rigid and patriarchal norms. As Campbell puts it, the hero's return entails putting the learned wisdom into practice so that he/she shares the benefits gained on the journey.
\end{abstract}

Keywords-Alice in Wonderland; hero's journey; process of individuation; self-development.

\section{INTRODUCTION}

In the pre-modern world, mythology was indispensable. It helped people find meaning in their lives, as well as revealing regions of the human mind that would otherwise remain inaccessible.

The renowned mythologist Joseph Campbell states that with the myths, humans, consciously or unconsciously, are inserted into the local organization, both emotionally and intellectually. Man, says Campbell (1992, p.16), "cannot maintain himself in the universe without belief in some arrangement of the general inheritance of myth. In fact, the fullness of his life would even seem to stand in a direct ratio to the depth and range, not of his rational thought, but to his local mythology."

Stories of gods and heroes descending into the depths of the earth, battling monsters and traversing labyrinths, have brought to light the mysterious mechanisms of the psyche, showing people how to deal with intimate crises. Accepting it as it was understood in previous societies, the myth designates a true story and not simply as a fable or an invented and unconnected story. These ancient societies gave meaning to the world through myth (CAMPBELL, 1992).
Campbell (1992) states that when the myth appears in the form of entertainment, it is not taken seriously, however, when it emerges in religious contexts, the myth is not only accepted as real but also considered revelation of truths of the respective culture and reveals from where their spiritual authority and temporal power derive.

The individual in previous historical periods was totally absorbed and integrated with nature, with its cycles of life and death, and regarding dealing with the land, since it was believed that from it, derived all of existence and continuity. (CABREIRA, 2006). With modernization, man has lost his capacity for symbolic production, which now has a psychic importance, since the unconscious preserves this capacity.

In this way, the connection between archaic myths and symbols of the unconscious is of great value for analytic work, since it allows interpreting of the symbols both in their universal historical aspect and in their psychological sense, as we shall see in the symbolic relation between the saga of the hero and the egoic development of the protagonist of the film - Alice.

When Freud and Jung began the modern investigation of the soul, they instinctively turned to classical mythology to 
explain their theories, giving a new interpretation to the old myths.

In this sense, the archetype of the hero is something very present in the contemporaneity. In films, novels, books, and others, the heroic sagas are constantly counted and retold, which demonstrates its structuring aspect of the psyche. The challenges of the hero represent the struggle of the ego's development against the regressive forces of the unconscious, as Henderson (2008) explains. The hero's trials represent his symbolic death for later rebirth, as they allow the "ego-hero", contact with his shadow, the occult, repressed aspects of the personality.

Through symbolic death (Catábase or initiatory rite), the hero becomes more aware of his strengths and weaknesses, reaching the necessary maturity to overcome the challenges of his journey. Thus, the hero's archetype is associated with rites of passage, fundamental for structuring consciousness, through the mythologema of the hero who kills the monster, as we will see in the Alice in Wonderland movie, where Alice kills the Jabberwocky, the dragon, which represents the obstacle that prevents her from raising her consciousness to the next level. Alice's dragon is that hidden force that prevents her from being who she really is in her divine essence and not simply following the social norms around "being a woman", taking into account the time in which the story occurs.

The film is directed by Tim Burton and based on the work of the writer Charles Lutwidge Dodgson, under the pseudonym Lewis Carroll, in 1865. The film portrays the journey of the hero lived out by the protagonist of the tale, Alice. A brief psychological analysis is made of the relationship between the fantastic narrative and the individuation process of the protagonist, and the symbolic representations in her psychic development. Considering the context of the time in history and the social role of women in the nineteenth century, the symbolism of diving into the own unconscious is discussed, as well as elements of life and a few aspects of the protagonist's psyche. The hero's journey reflects the transformation and growth that Alice went through.

The hero's journey was elaborated by Joseph Campbell in his famous book The Hero of a Thousand Faces, in which the author describes hidden patterns in mythology represented by the twelve stages experienced by the hero:

1. Ordinary World

2. Call to Adventure

3. Refusal of the Call

4. Meeting the Mentor

5. Crossing the First Threshold
6. Tests, Allies, Enemies

7. Approach to the Inmost (Hidden) Cave

8. Ordeal (Probation)

9. Reward (Seizing the Sword)

10. The Road Back

\section{Resurrection}

\section{Return with the Elixir}

This model is universal and occurs in all cultures, in all ages. The variables are infinite, equating the number of singularities in human existence, as Vogler (1998) puts it, but its basic form remains constant. "The hero's journey is a set of extremely persistent elements, flowing ceaselessly from the deepest layers of the human mind" (VOGLER 1998, p.33). The details differ, but they are fundamentally the same.

The perspective of Campbell's thinking is equivalent to that of the Swiss psychologist Carl G. Jung who wrote about the archetypes, characters, or energies that are constantly repeated. For Jung (2000), archetypes are values, beliefs passed on to succeeding generations, they represent our ancestral baggage even though we are not aware of them. Archetypes are models, which are often naturalized and therefore unnoticed.

Sinzato (2007, p. 62) contends that "archetypal images are contents that people do not know they know about, but when they come into contact with them, they capture their essence as if they are remembering something known." For example, as the author points out, St. Paul felt he was more than a nomadic weaver because he had the conviction that he was a messenger of the Lord. St. Paul seized the archetype of the messenger and thus felt himself more than a mere craftsman.

Jung (2000) realized the analogy between his patients' dreams and mythological archetypes, and this led him to hypothesize that both come from a common source, the collective unconscious. For this author all the archetypes are in the collective unconscious, and therefore, are unknown to humanity.

Therefore, for Campbell (1992) the myth is a narrative of symbolic character. The author noted that the mythology was the same under a variety of customs, that is, the author believed that there was a common sense among all mythologies. In his studies Campbell extracted an explanatory summary that applies to all the myths, to what he denominated monomyth. The hero's journey illustrates the trajectory of challenges, struggles and achievements experienced by the hero, who is each of us, humans.

The hero's journey, says Campbell, is marked by physical and spiritual prowess. Every path traveled by the hero 
follows in the sense of self-development, of selfknowledge, so the hero's journey is not understood as a warrior journey, but as a "liberation" of being. It is hoped, contributes Sinzato $(2007,54)$, that "as a hero, you free yourself from the darkness of unknowing yourself and seek the light, pursuing the delphic maxim 'Know thyself"'.

The trajectory of the hero's journey, according to Cabreira (2006), is marked by complications, trials and lessons that the hero must undertake in order to achieve his inner development.

Screenwriting analyst Christopher Vogler, a specialist in fairy tales and myths, and consultant of the Disney feature films The Lion King and The Beauty and the Beast, in his book The Author's Journey - Mythical Structures for Authors related Jung's concepts and the mythical studies of Campbell. The book reappears (VOGLER, 1998) with the archetypes and the twelve stages of the hero's journey. The book serves as a guide for writers who seek to create depth in stories and characters that look real in the eyes of readers. In this book the author succinctly exposes gender problems within the hero's journey, according to Vogler (1998), this theory shows only the male perspective; "there can be a real difference in the form of the journeys of men and women. The journey of men may be, in some respects, more linear, evolving from one external goal to the next, whereas the journey of women may develop in a spiral, into the interior and the exterior "(p.20).

Mauren Murdock, then Campbell's student, also noted that the hero's journey does not encompass the female inner universe, so the researcher wrote a book; The Heroine's Journey: Woman's Quest for Wholeness. In it, the author elaborates the journey of the heroine structured in a circular form, formed by ten stages with a contemporary vision of the yearnings and the positions that women occupy today in the society. Murdock (1990) argues that it is still possible in contemporary times to observe how much women live out the hero's journey. This is because the father is the figure of power and success in the home. This fact makes the woman in her earliest stages of human development identify with the paternal figure by denying the feminine values that were once sacred in the past, such as sensuality, intuition, creativity.

This fact is observed in the performance of the protagonist of the film, Alice, who makes the journey of the hero and not of the heroine. The beginning of the film evidences Alice's strong identification with the paternal figure, influencing her decision to continue her father's dream to explore the unknown and unexplored continents until then.
In addition, the hero's journey was used in several doctoral thesis and research. Carmem Isabel Pereira Sinzato (2007) of the Post-Graduation Program in Production Engineering at the Santa Catarina Federal University, in her thesis "Conhece-te a ti mesmo: uma proposta de desenvolvimento da Maestria Intrapessoal de Líderes", (Know thyself: a proposal to develop the Intrapersonal Leadership Mastery), created a method inspired by the journey undertaken by hero Hercules, in its conceptual basis, the leader's journey towards intrapersonal mastery. Community leaders who focused on the development and personal transformation of their collaborators participated in this research. It is thus a spiritual, servant and conscious leadership. According to the researcher, leaders who are participants in this type of movement are generally those who seek self-knowledge and are therefore aware that this movement is not from the outside to the inside, but rather the opposite, says the author. "It can be said that the formation of true leaders passes through the exercise of a posture of an authentic and balanced life ... " (SINZATO, 2007, p.14).

This study, points out Sinzato (2007), contributed to the personal development of leaders and therefore to the humanized development of organizations. Besides it this research contributes significantly to the proposal of the respective article regarding the relevance of selfknowledge for personal and social development, considering that we are all One, united and integrated. Thus, when a person manages to deepen their knowledge of self and attain personal mastery, they also contributes to the development of others around them: "He who makes the journey of the hero enters the lands of intrapersonal mastery, finds knowledge of self, changes his gaze upon to himself, upon others and upon his world and returns transformed" (SINZATO, 2007, 53).

Another Thesis of the Interdisciplinary Doctoral Program in Human Sciences at the Santa Catarina Federal University - (UFSC) by Regina Helena Cabreira (2006) is "A Condição Feminina na Sociedade Ocidental Contemporânea - Uma Releitura de A Letra Escarlate de Nathaniel Hawthorne." (The Female Condition in Contemporary Western Society - A Re-reading of The Scarlet Letter by Nathaniel Hawthorne). This paper deals mainly with the need to value the "feminine" aspect in our lives and societies. From the urgency of questioning and reflecting upon the role of women in contemporary Western society to the various types of stigmatization that women still suffer in the environments in which they live.

To that end, Cabreira (2006) analyzed the novel The Scarlet Letter (1850), by Nathaniel Hawthorne. He presented, firstly a mythical-historical view, where he rescues the concept of "feminine", through the works of 
Marija Gimbutas in The Language of the Goddess (2001) and Edward Whitmont in The Return of the Goddess (2001), among others. Second, Joseph Campbell's theory of the hero's journey in The Hero of a Thousand Faces (2002), with an emphasis on the "heroic trajectory" and how it applies to the analysis of the deep structure of the novel, and the trajectory of the heroine Hester Prynne. Thirdly, the symbolic study of the content of the novel, which shows the deep meaning of the elements that make up the mythical trajectory in question.

The relevance of this study to the symbolic and mythical analysis through Alice's journey, as well as the process of maturation of the protagonist of the film, is due to the redemption of the female. Cabreira (2006) makes a beautiful interpretation and through her bibliographical research of this aspect, the author reminds everyone about "Being-Woman", which in turn has been misrepresented over the last few centuries and, despite the many efforts of academic movements, feminists and others, there are still some discrepancies between women and men in social, cultural and organizational life.

The author illustrates the life of Hester Prynne, a woman who married an older man, whom she did not love, but as was common at that time, in 1642, when immigrating to a distant and lonely place, she gets romantically involved with the local pastor and gets pregnant of him. Hester is convicted of adultery and is arrested, in addition to being condemned by society to live the next years away from everyone.

This is the story of many women, not necessarily in the same scenario, but similar. And even today it is possible to observe an unequal and unjust society. It can be said, contributing to Jung's concept of the collective unconscious that, since its content and value are unknown to humanity, the historical and cultural construction of the role and value of women in society is deeply rooted and distorted in the collective unconscious.

Challenges to transmute such symbolic value are pointed out and articles such as that of Cabreira (2006), Sinzato (2007) and Picchia and Balieiro (2010), including the respective analysis of Alice's journey, contribute to reconstruct the Being-Woman.

Corroborating to the debate, Campbell (2015, p.15): Many of the difficulty women face today are due to the fact that they are entering a field of action in the world that was previously reserved for men and for which there are no female mythological models. Consequently, the woman finds herself in a competitive relationship with man and doing it they may lose the sense of her own nature. Her prescribed role was to give birth and raise children. The male role was to sustain and protect. These roles were biologically and psychologically archetypal. But what has happened now is that women have been relieved to some extent from their traditional attachment to the home. They have entered the field and the forest of individual search, conquest and personal fulfillment, for which there are no feminine models (....). The challenge of the moment is to flourish as an individual, neither as biological archetypes nor personalities that emulate the masculine. Again, there are no models in our mythology for an individual female quest. Nor are there models for the man who marries an individualized woman. We are in this together, and we must resolve this together, not with passion (which is always archetypal), but with compassion, nurturing each other's growth with patience.

Another work that contributes significantly to this systematic review, which in turn was published as a book, is O Feminino e o Sagrado: mulheres na jornada do herói, (The Sacred Feminine: women in the journey of the hero), authors Beatriz Del Picchia and Cristina Balieiro (2010). The writing project for this book, the authors pointed out, was originally based on another book: "O jardim sagrado a dimensão espiritual da vivência femina" by Sherry Ruth Anderson and Patricia Hopkins, published in Brazil in 1993 and in the United States in 1991 with the original title The feminine face of God - The unfolding of the sacred in women. The reading of this book, as reported by Picchia and Balieiro (2010), had a strong impact on them because both were strongly interested in the issues of the feminine, mythology and manifestations of the sacred in everyday life. Fifteen women participated in this study, all with some relation to the search for the knowing of themselves. It was more than fifty hours of recording and about five hundred pages of transcription, with a total of four years of work, between the project, the interviews and the analysis of the data. In this study the authors observe how the hero's journey lived by the participants was not linear but rather circular, they verified the relevance of this journey and the impact of this trajectory in their lives. In addition, this study proves the observations of Campbell (2007) when relating myths to the journey of the hero.

One can therefore ascertain the different facets and possibilities for the use and interpretation of the hero's journey. All, however, refer to the pursuit of selfknowledge and self-development. This is not an easy, but necessary, path. Wonder: what would Alice's life be like if the protagonist of the movie had not invested in her journey into Wonderland? It is likely that she would have married a duke she was not in love with, would have children, and would be subservient to the duke and social rules. Alice would possibly remain in the female standard of the time. She would suffer internally and would not have the strength to express her divine gift, which is 
nothing more than the encounter with oneself, with the sacred, the divine.

Alice's Wonderland Journey will begin with a brief interpretation of Alice in Wonderland using the Hero's Journey as a methodological basis as well as the research and studies previously cited.

\section{THE HERO'S JOURNEY REPRESENTED IN THE EXPERIENCE LIVED BY ALICE}

2.1 The hero's journey - The rupture: (2.1.1) Everyday world; (2.1.2) Call to adventure; (2.1.3) Crossing the first threshold

\section{(2.1.1) Everyday world}

The everyday world is not a stage of the journey, but the place from where the hero left and where he will return to. It is the world in which each person lives, for example, Picchia and Balieiro (2010) report that the everyday world of their participants [in their study] is the state of São Paulo. Meanwhile, Hester Prynne's journey runs from 1642 to 1649 , in seventeenth century Salem, Massachussets (CABREIRA, 2006). In her analysis Cabreira (2006) points out that Hester isolates herself from life as she knows it, gradually. First, she departs from her husband and her native land to go to an unknown place; then she is condemned to isolation within the society of Salem for her crime and then builds her life and that of Pearl, her daughter, from the circle of approximation that separates them from the other inhabitants.

The film Alice in Wonderland brings a representation of the psychic growth process of the protagonist, and her journey can be analyzed from the Jungian psychological perspective of integrating the various aspects of her psyche to face a major challenge in her life, when, in the story directed by Tim Burton, she is requested in marriage. When faced with the situation of decision, Alice apologizes, and leaving the place plunges into her unconscious and finds several forgotten and immature aspects of her psyche that she needs to know, recognize and integrate for the maturation of her psyche.

It is interesting to note that both Alice and Hester, fiction and reality, are exposed to society. Hester, when she is convicted of adultery and Alice when asked in marriage. In the same way, it turns out that both aim to transgress their role with society. They seek to break with the standardized model set for women, which was built and valued throughout the history of mankind.

Since the 1960s social and women's movements fought to get rid of this antagonistic model. Contributing to the above, is Cabreira (2006, p. 11/12): "Women have long struggled to form, maintain and sustain their identity, moral integrity, public and private life, and struggle to maintain and at the same time, rescue, their innate characteristic, their instinctive nature".

\section{(2.1.2) Call to adventure}

"[...] the call rings us the curtain, always, on a mystery of transfiguration - a rite, or moment, of spiritual passage, which, when complete, amounts to a dying and a birth. (1968, pg. 51)

(Joseph Campbell, 2007, p.61)

This first stage, alluded Picchia and Balieiro (2010), means that destiny summoned the hero and transferred him from the center of society to an unknown region.

Campbell (2007) states that the call usually occurs by mistake or mere chance, the frog emerges to rescue the ball from the bottom of the pond, the girl observes the elegant rabbit running through the garden, the young girl falls in love with the shepherd and gets pregnant. But this event reveals a new and unsuspected world in which the individual will encounter forces that are unknown to them.

In the initial situation of the film Alice faces the need to take control of her own life or submit to social expectations and live the consequences. When faced with the challenge of establishing herself and deciding her fate, the character turns to her unconscious and childish world in search of her own references to strengthen and face the issue. There is a well-known therapeutic mental process in which life situations are repeated so that one can learn the lesson, which Jung reveals as a psychic retreat from time to face an initially insurmountable obstacle with the resources of the time. At the beginning of the movie Alice dreamed of Wonderland and had the affectionate comfort of her father, and it is to these loci that she turns to in order to elaborate her childhood affective issues, for this moment of the maturing that life demands of her.

At the beginning of the story there is the conflict between the social understanding of what would be appropriate and Alice's yearnings for living her own life and freedom. We can relate the various characters to the distinct aspects of the psyche, among them the White Rabbit and Absolem can represent the unconscious and instinctive impulses of Alice when the time of her initiation arrives in the journey of the psychic growth. The White Rabbit embodies the need for the ego to awaken to certain values and recognize its many facets in an integrative process.

The White Rabbit plays the role of reminding Alice about the arrival of the 'call' to awaken, to delve into herself and to deepen her self-knowledge. In Campbell's (2007) terminology the White Rabbit represents the herald and announces the transition from one phase to the next, the challenge, the call to mission. It is the figure of the herald 
who informs the psyche that it is ready for transformation, for the awakening of the Self.

Alice apologizes to the guests and runs after the rabbit accepting the Call to Adventure to know the Self.

\section{(2.1.3) Crossing the first threshold}

Having crossed the threshold, the hero walks in a dreamlike landscape populated by curiously fluid and ambiguous forms, in which he must survive a succession of trials.

(Joseph Campbell, 2007, p.102)

This step is represented by the action after acceptance. "A stage in which we move from decisions to action" (PICCHIA and BALIEIRO, 2010, p.33).

In the movie Alice accepts the invitation of the White Rabbit and, apologizing to the guests who eagerly awaited her response to the duke's request in marriage, rushes to join him. She does not understand the situation very well, but she knows that it is necessary to follow her instinct. Upon reaching the tree, Alice plunges into her own feminine for the transmutation of the childish aspects of her consciousness and emotional growth into a more mature and autonomous consciousness.

The tree represents a portal, a threshold to another level of consciousness. At this point Alice's journey begins, in the depths of her Self. We also have Hester as a heroine in search of something she was missing, something that had been "usurped" from her life: her youth, the possibility of being fully realized as woman, to live a great love and to become a mother. Her marriage with Chillingworth, a much older, mature man, meant a break in Hester's life and the possibilities she would have with a mate whom she truly loved (CABREIRA, 2006).

As Picchia and Balieiro (2010, p. 37) put it, "The universe conspires in favor of those who are willing to undertake the journey towards the deepest parts of themselves."

2.2 The hero's journey - Initiation: (2.2.1) Meeting with the master; (2.2.2) Learning; (2.2.3) Crossing of new thresholds;

This is the beginning of the second of the three phases of the hero's journey. At this stage the transformation of the hero and his/her perspectives, his/her values and world views take place. The path traveled is what provides the transformations and consolidates them in their psychic and emotional structure. This stage provides a rebirth and for this, a death is necessary. We may have to give up projects and dreams prior to this experience, false beliefs, illusions and our self-image will also be re-signified. Therefore, the title Initiation, which implies the 'death' of an old self, enables a rebirth of a new self.

\section{(2.2.1) Meeting the Mentor}

For those who did not refuse the call, the first encounter of the hero's journey takes place with the protective figure [...], who provides the adventurer with amulets that protect him against the titanic forces he is about to encounter. [...] This figure represents the benign and protective power of fate.

(Joseph Campbell, 2007, p.77, 76)

During the adventure Alice meets The Hatter, who represents Alice's mentor. The role of the teacher is that of a master, a guide, a spiritual leader. The presence of the Hatter exerted a transforming power for Alice and gave her direction. He challenged Alice to believe in herself, to believe that she is the real Alice, also challenged her to accept the idea of facing the Jabberwocky, the dragon that in turn symbolizes the greater fear of the protagonist.

Mentors, as Campbell puts it, are those who have already fought their battle and are willing to aid the hero. As mythical figures the mentors can be a bird, a horse or similar figures. The mentor will help the hero in his/her trajectory, but it is worth noting that he is not an end, that is, in order to complete the journey and put into practice the knowledge acquired by the encounter with the mentor, the mentor will have to disappear, thus providing the hero the opportunity to integrate knowledge into his/her own psyche.

The expression "muchness" used by the Mad Hatter draws attention to a point, where it is evident that the protagonist needs to broaden her vision and deepen the awareness that she has of herself. Her mentor shows Alice that she needs more intensity and depth in her contents to accomplish her destiny; to be complete she needs to take responsibility for her own life. The Self possesses free will - as it is affirmed, but within the limits of the field of consciousness (JUNG, 2011), that is, the wider the field of consciousness, the more possibilities are presented and can be realized by the self.

\section{(2.2.2) Learning}

You unlock it [the way] when you find someone who helps you unlock it. This can come from a person, properly speaking, or from an experience ... or from an illuminating book ... All you need is a thread from Ariadne ... not always easy to get. ..It's good to have someone to count on to give you a clue.

\section{(Joseph Campbell, 2007, p 173)}

The character Absolem brings the questioning about oneself, "Who are you?". It symbolizes the metamorphosis of the psyche in its process of psychic growth, and brings the need to die in the present stage of consciousness and to be born into a new life. His role is to provoke the 
questioning of who Alice really is and what are her own values and references, which should guide her through her adult life. Absolem challenges her to understand herself better and more deeply.

At this stage Alice must get in touch with her potential, awaken in herself her divine power, recognize that she is the real Alice. Campbell narrates that man's quest in life is to conquer himself, but for that to occur he will go through various trials / challenges. It is the challenges that will enable the hero to come out of ignorance and come into wisdom.

\section{(2.2.3) Crossing of new thresholds}

The original departure for the land of trials represented only the beginning of the long and truly dangerous path of the achievements of initiation and moments of enlightenment. You now have to kill dragons and surmount amazing barriers - over and over again.

(Joseph Campbell, 2007, p. 110)

An important step in the process is manifested by the protagonist to the dog Bayard, when she expresses her awareness and new level of empowerment: "Since I fell in that rabbit hole I was told what to do and who I should be. I was shrunken, stretched, scratched and stuffed into a kettle. I was accused of being and not being Alice, and this dream is mine! I'll decide from now on." In making the decisions from then on Alice shifts her route to reach her destination, becoming more determined and conscious.

The protagonist goes to meet the Queen of Hearts who in the Jungian approach represents the imbalance between functions of the psyche, where the emotion function is in the shadow, while the thought function is exacerbated. The movie medium represents this with the Queen's enhanced head and her emotional immaturity, with fits of anger and repression of emotion.

The Queen of Hearts brings the Shadow when she presents a cruel and insensitive attitude before all, is a dictator and orders that the heads of those who defy or threaten her power are cut off. The Queen of Hearts has no emotional maturity. Alice's identification with the Queen of Hearts brings the disconnection with her own feelings and the blindness of power. Emotional maturation and shadow integration are some of the stages of psychic growth that Alice needs to live out to meet her challenges in life.

However, although Alice is identified with her shadow the Queen of Hearts, she surrenders herself for a period. For Campbell (2007) this process is part of the journey of the hero, the author says that the hero is the one who knows when to surrender and what to surrender to.

As the author narrates, the hero can only succeed in diving into him-Self because he has a goal and a method. It is evidenced as Alice's goal: to know herself, to rescue her divine Self; and as a method, the deepening into her inner self.

For this to be possible it is necessary to meet with her own shadow, so the symbolism of this part of the film is of much relevance. Alice confronts and aligns with her shadow for a period. Conviviality with the Queen of Hearts enables Alice to know this aspect of her previously unknown psychic structure.

In addition, Alice makes allies and recognizes enemies. A very symbolic and significant scene is the one where Alice makes an exchange with the Queen of Hearts' "little pet", the Bandersnatch. She returns his eye as he allows her to take the key that opens the chest in which the Vorpal sword is. Only in possession of it can the great battle with the dragon be fought.

The maturing of Alice is verified when establishing this bond. Alice returns sight to the monster; the monster represents an aggressive and primal instinct of Alice. A repressed aspect of which she had much apprehension and fear of. Interesting to note that the same evil could both kill her and give her life because, remembering that Alice was wounded by the Bandersnatch at the beginning of the film and such an injury could lead her to death. Upon receiving his eye again, Bandersnatch licks the wound on Alice's arm and heals her.

The symbolism of this part of the film reminds us that by shedding light on certain aspects of our shadow we can save ourselves from our own tyrannism and selfishness that are projected on most occasions onto relationships. Alice, when mastering one of her aggressive instincts wins the key that will open new paths. The Vorpal sword, symbol of will and determination, at this moment Alice strengthens her ability to overcome circumstances.

Another aspect explored are the proportions of Alice who needs to adjust to achieve her goals, the story brings a symbolic message of proportionality, being too large to go through the door, or too small to reach the key, Alice is at times too tall, sometimes too short for her true height, what is the exact measure of Alice's armor and height? This represents the inflation and deflation of the Ego, where people believe than what they are, overrating and underrating, which occurs due to identification with unreal figures beyond human proportion. When confronted with the two Queens, Alice integrates several dark and unknown aspects of her feminine. The Queen of Hearts rules the living things, and has the power over their lives, in her we see the puncture of life, the blood of wrath.

It is, however, the White Queen who makes the potion that will bring the appropriate size to Alice, which curiously, is made of elements that have become useless to her psyche, 
represented by parts of dead bodies. In her feminine integration Alice brings to her consciousness the Shadow and the dead and forgotten aspects of her psyche, so that they are recognized as an integral part of her.

While, for Hester, as analyzed by Cabreira (2006):

The crossing of this first threshold is closely linked to the earlier stage of Hester's life and the condition in which she marries Chillingworth. Throughout the novel we know that it was a loveless marriage, at the insistence of Chillingworth, a fact common at the time, when a young and poor girl had little choice but to join a much older man of superior social standing. Hence her unconscious need to seek a new life, a new trajectory, even if it is in an unknown land and in a society with such austere values.

Thus, Hester, in accepting her adventure alone, sets out in search of her destiny and the salvation of an undesired situation.

\subsection{The Hero's Journey - Return}

The complete circle, the norm of the monomyth, requires that the hero now begins the work of bringing the symbols of wisdom, the Golden Fleece, or the sleeping princess, back to the human realm, where the blessing achieved can serve the renewal of the community, the nation, the planet or the ten thousand worlds.

(Joseph Campbell, 2007, p.195)

This phase is the last of the three phases of the journey, ending the initiatory process which, the hero has passed. The hero, now transformed by rupture and initiation, must return to his/her everyday world by bringing the transmuting trophy.

Alice takes with her the knowledge acquired throughout her path, and all knowledge generates commitment, so the hero has a responsibility to share that knowledge with others around her so that they too can, in their own way, transmute and achieve a new level of consciousness.

The trails Alice went through gave her opportunities for growth and maturity, and so she returns to her engagement event now, as the caterpillar Absolem says to Alice: "you're closer to be the real Alice." In the sense of Alice having rescued a lot of own herself.

After experiencing her journey, Alice no longer accepts frames for her thinking, she is freer to express her divine gift in the world.

As Alice steps out of her daily life and begins to walk through the newness, other initiatory processes may be necessary in her new life trajectory, the challenges occur as a form of growth, and so we go, step by step, corroborating with what Campbell claims: to get somewhere it is necessary to undergo a few trials. In addition, the author adds, "the complete circle, the monomythic norm, requires that the hero now begin the work of bringing the symbols of wisdom ..." (Campbell, 2007: 195).

The hero not only takes responsibility for his/her personal development but also contributes to the transmutation of certain circumstances of his locality. Alice returns to the engagement event and exposes some obscure and mediocre facts of that society. Hester, says Cabreira (2006), despite her misfortunes and isolation for seven years, proves to be beyond the moral and almost physical suffering imposed upon her, deciding to return to Salem and help those who ha

\section{CONCLUSION}

Through the brief analysis of the narrative of the movie Alice in Wonderland, we follow the archetypal journey of the heroine Alice, in her process of self-knowledge and empowerment to decide on her own life instead of fulfilling the social role of women in her day.

The analyzed studies that contributed to this systematic review enabled us to investigate how the myth symbolizes the dynamics of the psyche.

Remembering that myths, fairy tales and others, are often told through movies, soap operas, etc., to remind us of their archetypal images and symbolism. The mythical journey proposes to develop in the individual the consciousness, the knowledge of his or her own strengths and weaknesses to prepare him/her for life.

Campbell elaborated the hero's journey from observations of various myths of the world and concluded that in myths there is a basic structure governing them, and although myths change according to each locality, they remain the same in their basic structures, since the symbolic values are the same.

It was noted that the consciousness of Alice, the protagonist of the film, expanded and transmuted certain fears. In accepting the challenge of killing the dragon Alice agreed to eradicate a part of her psychic structure that prevented her from revising the Self. This last fact is not an easy task, as Sinzato (2007) reminded us, the indepth encounter of the Self often brings discomfort because this process, when effective, accesses content of the unconscious, which is not always easy to bring to light, to be incorporated and transcended.

In the study of Picchia and Balieiro (2010) it was verified how much the hero's journey is part of daily life and accepting the Call to Adventure provides profound changes that give life sense and meaning. 
Alice must now return to her midst, transfigured, and teach the renewed life lesson she has learned.

\section{REFERENCES}

[1] CABREIRA, Regina Helena. A Condição Feminina na Sociedade Ocidental Contemporânea - Uma Releitura de A Letra Escarlate de Nathaniel Hawthorne. Tese (Doutorado Interdisciplinar em Ciências Humanas) - Programa e Doutorado Interdisciplinar em Ciências Humanas. Universidade Federal de Santa Catarina. 2006.

[2] CAMPBELL, Joseph. O herói de mil faces. São Paulo: Pensamento, 2007.

[3] CAMPBELL, Joseph. As máscaras de Deus: mitologia primitiva. São Paulo: Palas Athena, 1992.

[4] CAMPBELL, Joseph. Deusas: os mistérios do divino feminino. São Paulo: Palas Athena, 2015.

[5] JUNG, Carl Gustav. Os Arquétipos e o Inconsciente Coletivo. Petrópolis, Rio de Janeiro: Vozes, 2000.

[6] JUNG, Carl G. O homem e seus símbolos. Rio de Janeiro: Nova Fronteira, 2008

[7] HENDERSON, Joseph L. Os mitos antigos e o homem moderno. In: JUNG, Carl G. O homem e seus símbolos. Rio de Janeiro: Nova Fronteira, 2008, p. 133-206.

[8] MURDOCK, Mauren. Heroine's Journey: Woman's Quest for Wholeness. Boston: Shambhala, 1990.

[9] PICCHIA, Beatriz Del; BALIEIRO, Cristina. O feminino e o sagrado: mulheres na jornada do herói. São Paulo: Ágora, 2010.

[10] SINZATO, Carmem Isabel Pereira. Conhece-te a ti mesmo: uma proposta de desenvolvimento da Maestria Intrapessoal de Líderes. Tese (Doutorado em Engenharia de Produção) Programa de Pós-Graduação em Engenharia de Produção, Universidade Federal de Santa Catarina. Florianópolis. 2007.

[11] VOGLER, Christopher. A jornada do escritor: estruturas míticas para escritores. 2. ed. Tradução Ana Maria Machado. Rio de Janeiro: Nova Fronteira S.A., 1998. 